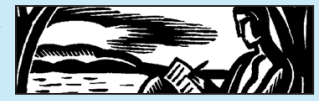

\title{
'Which I Presume is Permitted, Since We Are Talking About A Writer.' Lateness, Memory, and Imagination in Literary Autobiography
}

\author{
Melissa Schuh
}

Christian-Albrechts-University Kiel

\begin{abstract}
In Summertime, a fictional biographer, $\mathrm{Mr}$ Vincent, conducts interviews with contemporaries of the novelist J.M. Coetzee for a biography of the late author. However, every claim made about the late Coetzee by the characters in Summertime is composed by the author himself, so the hidden, yet obvious presence of the novelist gives the book's supposedly biographical outlook an autobiographical twist. Summertime's Coetzee is distinctly both alive and dead. I propose to analyse works such as Summertime as literary autobiographies that employ narrative strategies otherwise found in fiction in order to creatively explore lateness, belatedness, and a sense of ending with regard to their writing life. Performative contradiction, as a deliberate stylistic manifestation of paradoxical contradictions, is a result of such narrative strategies. This enables a portrayal of memory and sincerity in autobiography that acknowledges the fraught nature of these notions. Drawing on autobiographical writing by novelists, such as Coetzee, Philip Roth, and Günter Grass, this article analyses the use of tense and fictionality to create performative contradiction. It shows how the novelist's memory and imagination engage with the ever-present possibility of death to subvert traditional ideas of lateness as well as perceived limitations to the temporality of autobiographical writing.
\end{abstract}

Keywords: late style, memory, literary autobiography, fictionality 


\section{ABSTRACT IN GERMAN}

In Summertime führt Mr Vincent, ein fiktionaler Biograph, Interviews mit Zeitgenossen des verstorbenen Schriftstellers Coetzee durch. Allerdings ist jede Aussage über den verstorbenen Coetzee, die von Figuren in Summertime gemacht wird, vom Autor selbst verfasst. Daher verleiht die versteckte und dennoch offensichtliche Gegenwart des Autors dem biographischen Rahmen des Texts eine autobiographische Wendung. Der Coetzee von Summertime ist sowohl tot als auch am Leben. Werke wie Summertime können als literarische Autobiographien beschrieben werden. Diese setzen narrative Strategien ein, die in fiktionalen Texten üblich sind. Dabei werden auf kreative Art und Weise Spätzeitlichkeit und die Gegenwärtigkeit von Tod und Ende mit Bezug auf das schreibend verbrachte Leben dargestellt. Auf diese Weise entsteht eine Schilderung von Erinnerung und Aufrichtigkeit im Autobiographischen, welche die Zwiespältigkeit dieser Begriffe in den Vordergrund rückt. Am Beispiel autobiographischer Werke von J.M. Coetzee, Philip Roth und Günter Grass untersucht dieser Artikel die Verwendung von Zeitformen und Fiktionalität im Hinblick auf die Erzeugung performativer Widersprüche. Dieser Beitrag zeigt, dass das Zusammenspiel schriftstellerischer Erinnerung und Vorstellungskraft sich mit der immerwährenden Möglichkeit des Todes auseinandersetzt und traditionelle Vorstellungen von Spätzeitlichkeit und Spätstil sowie vermeintliche Beschränkungen von autobiographischer Zeitlichkeit und Form unterwandert.

Keywords: Spätstil, Spätzeitlichkeit, Erinnerung, literarische Autobiographie, Fiktionalität

You must be getting worried. What have I let myself in for? You must be asking yourself. How can this woman pretend to have total recall of mundane conversations dating back three or four decades? And when is she going to get to the point? So let me be candid: as far as the dialogue is concerned, I am making it up as I go along. Which I presume is permitted, since we are talking about a writer. What I am telling you may not be true to the letter, but it is true to the spirit, be assured of that. Can I proceed? ${ }^{1}$

How can the novelist portray a life spent writing fictions? Do our expectations of the autobiographical genre change when 'we are talking about a writer?' As one of Summertime's interviewees, who recount their acquaintance with the late John Coetzee, Julia poses questions about her own narrative that are fundamental to understanding both the conception and reception of autobiographical writing. Pretending to 'have total recall of mundane conversations,' missing 'the point' of a life narrative by digressing and 'making it up as [she] go[es] along' may violate the concept of an autobiography which is 'true to the letter,' but we have learned to accept it 
as 'true to the spirit,' as Julia assures us. Truth is indeed at stake but Julia's assumption of being doubted by her interlocutor amounts to more than a postmodern play on the slippery boundary between 'truth' and 'fiction.' Her questions and her subsequent confession of inventing or even lying are part of an autobiographical performance, one that speaks to the problem (and paradox) of autobiographically writing a novelist's life. One might ask, where is this novelist whose life is supposedly being written? J.M. Coetzee, the dead and therefore absent novelist-'character' and author of Summertime, from which Julia's statement is taken, is mentioned by her only in passing as a justification for taking creative license with her narrated dialogue. And yet, his presence pervades Julia's words fully, given that he has written Summertime, making this statement by Julia an act of autobiographical self-representation by Coetzee. This is indicated by the prominent feature of his name on the book's cover. Every claim and comment made about the late John Coetzee by the characters in Summertime is composed and crafted by the author Coetzee, so the hidden, yet obvious presence of the novelist gives the book's supposedly biographical outlook an autobiographical twist. Although Summertime is the third instalment in an autobiographical trilogy preceded by Boyhood and Youth, it significantly differs from the earlier works in its narrative framing. ${ }^{2}$ Summertime's Coetzee is both alive and dead, reaching beyond his own ending by imagining how his posthumous biography could be written.

It becomes clear that Julia's statement has distinct autobiographical significance for Coetzee. Her admission of 'making it up' becomes more than an assertion of reliability by addressing the inability to remember dialogue 'true to the letter.' Even more strikingly, her insistence a few pages later that '[she] really was the main character' while 'John really was a minor character' within her experience of events amounts to more than a differentiated view on autobiographical perspective. ${ }^{3}$ Due to Coetzee's invisible, yet dominant autobiographical presence in Summertime, her sensitivity towards the nuance of story-telling in autobiography becomes an ongoing commentary on the novelist's ultimate inability to tell their ${ }^{4}$ life story as factually true or 'true to the letter.' After all, Julia is part of Coetzee's autobiographical self-representation, and thus made up by him. And yet, Coetzee as an autobiographical subject emerges in Summertime as a product of characters and conversations who are writing John while Coetzee writes them. The novelist's position is contradictory in relaying truth and life through fiction, in remembering both fact and invention as mutual origin and product of one another, and in appearing sincere for not trying to be 'true to the letter' while 'pretend[ing]' as Julia to be 'true to the spirit.' Julia's statement encapsulates this contradiction, for she admits to 'mak[ing] [...] up' John although she is made up by 
Coetzee and her struggle to add to John's biography without colouring it as part of her autobiography mirrors the novelist's difficulty to convey a life spent writing fictions. Julia's assumption that invention is permissible 'since we are talking about a writer' contains the novelist's implicit question of how to tell truthfully and ethically what I will call a 'writing life,' a life characterised by invention and fictionality. ${ }^{5}$ Summertime, I argue, is an act of literary autobiographical performance. It performs Coetzee's complex engagement with the difficulty of a novelist's autobiography, highlighting the contradictory and even paradoxical nature of writing and reading novelist autobiography by presenting us with its impossibilities. Julia's reflection on the truth status, reliability, and sincerity of her remarks about John indicates these impossibilities. It also raises the kinds of questions I want to begin to answer with this article. How are truth and fiction rendered in regard to the novelist's life as lived through the creation of fictions? Which roles do lateness, a sense of ending, and the everpresent possibility of death play in the construction of autobiographical memory and sincerity? Can autobiographies by novelists reach beyond death through the use of fictionality?

In response to these questions, I turn to novelists whose works are steeped in fiction as the very essence of the authors, the writer's life - a life spent writing. My ideas rest on two key related notions. Firstly, that autobiographical writing by novelists can be described as literary autobiography: a product of creative and narrative strategies, aimed at testifying to the writing life as a complex, difficult, and fraught with the entanglement of contradictions. Secondly, the idea of performative contradiction as an autobiographical aesthetic. Performative contradiction is a notion which describes phenomena that have the qualities of an oxymoron. As Mark Currie suggests, performative contradiction 'can be defined as a discourse which claims one thing and does another. ${ }^{6}$ I want to show that literary autobiography is constructed with narrative strategies which contribute to an aesthetic of performative contradiction. The portrayal of autobiographical memory through such narrative strategies highlights the specific contradiction of remembering a life in the face of its inevitable ending that is inherent to the autobiographical project. Autobiographical writing therefore contains the impossible challenge to survive and go beyond death, although its writer cannot reach beyond the present moment. However, the use of fictional modes to create performative contradiction opens up the possibility of imagining futures and endings beyond the present. Although autobiography's temporality seems limited, fictionality can offer survival beyond the ending of death. To explore the potential of fictionality and performative contradiction in autobiography to subvert endings, I will focus on three acclaimed novelists, whose late 
works display a differentiated treatment of the writing life as suspended between fact and fictionality: J.M. Coetzee, Philip Roth, and Günter Grass. Specifically, I will analyse Coetzee's, Roth's and Grass's portrayal of lateness, memory, and sincerity as examples of performative contradiction working to convey difficulty and paradox as a form of resistance against endings and death.

\section{LATENESS AND STYLE}

As a writer he knew what he was doing, he had a certain style, and style is the beginning of distinction. ${ }^{7}$

My defining feature in conceptualising literary autobiography is an innovative stylistic quality in service of the autobiographical act, but it remains to be explored how exactly a novelistic style can be understood as an 'innovative' form for autobiographical writing. My sense of innovation, here, is not that fictionality in autobiography is new and thus groundbreaking in itself. Rather, the way in which contradictions between fact and fictionality, life and narrative are performed as a stylisation of complex autobiographical questions makes literary autobiographies by novelists - such as Coetzee, Roth and Grass - innovative in terms of evaluating literary life writing. Lateness and late style - a concept for describing late art that is heavily influenced by Edward Said - provides a lens through which this innovation can be observed as contributing to an aesthetic of performative contradiction in these novelists' autobiographies. Lateness and its aesthetic rendering through late style is chiefly concerned with endings, particularly the ending of a life and an oeuvre through death. It also relates to what Gerhard Richter has coined 'afterness' to conceive of a sense of having survived or outlived something or someone. ${ }^{8}$ Thus, lateness describes the very conflicting experience of anticipating the ending of death while also perceiving this afterness of living beyond the endings one remembers, the endings of other lives, relationships, and periods within one's life. The imminent link between late style and autobiographical writing can best be illustrated by the idea that lateness entails self-conscious and timely reflection in artistic creation: 'lateness is being at the end, fully conscious, full of memory, and also very (even preternaturally) aware of the present.. ${ }^{9}$ According to Said lateness is 'being at the end.' I will argue that literary autobiography's late style reaches beyond and resists endings by performing contradictory versions of lives and selves, pasts and futures, memory and imagination. 
This enquiry into the novelist's autobiography as a product of concerns about lateness relates to current issues within the field of life writing more generally, not only in regard to my own conceptualisation of literary autobiography as a form of self-referential autobiographical writing. These pertain to the permeability of existing genre categorisations and hybrid forms, such as autofiction. ${ }^{10}$ In recent years, life writing and autobiography studies have seen a surge in criticism that develops more differentiated ways of assessing the increasingly blurry genre boundaries between fiction and non-fiction, novel and memoir, biography and autobiography, and combinations thereof. Conventions of strict categorisation have been criticised in favour of notions that account for the permeability between text types that fall into the broad spectrum of life writing. By showcasing how novelists respond to struggles with autobiographical self-representation through the stylistic rendering of lateness, this article aligns itself with current approaches that challenge the field of life writing. Such approaches call for criticism to take the hybridity and contradiction into account which becomes obvious in more liminal cases, such as autobiographical writing by novelists. Compared to other genres of autobiographical writing, such as the celebrity or the political autobiography, autobiographical writing by novelists is freer in interrogating the boundaries between non-fiction and fiction due to its close association with literary fiction. While the focus of this article lies with the novelist and the writing life, as well as Coetzee, Roth, and Grass in particular, it also responds to what Leigh Gilmore perceives as 'the ethical turn in lifewriting studies' ${ }^{11}$ by acknowledging the narrative affirmation of difficulty through stylistic innovation as more than just a product of postmodern playfulness. Late style will, thus, emerge as a factor that contributes to an aesthetic of performative contradiction in literary autobiography.

As Karen Leeder outlines in her article in the New German Critique themed issue on 'Figuring Lateness in Modern German Culture,' 'late style' as a theoretical approach has gained considerable significance over the last decade by extending its conceptual reach from musicology and art history into cultural and literary studies fields. ${ }^{12}$ Lateness can be seen as a modern condition which unites a 'sense of an ending,' as conceptualised by Frank Kermode, ${ }^{13}$ with a notion that Richter - as mentioned earlier - describes as a "particular figure of modernity, that of following, coming after, having survived, outlived, or succeeded something or someone: what in broad terms, I wish to call afterness. ${ }^{14}$ Ben Hutchinson shows that a broader understanding of 'lateness' can resonate beyond the formal aesthetic focus of late style to reconfigure our impression of the literary history of modernity. This conception of lateness is particularly interesting because it stresses the 'creative construct' over the critical 
tool. Conceiving of lateness as a broad creative practice points towards late style as a product of creative challenges in life and writing. However, Gordon McMullan and Sam Smiles voice scepticism at late style's position in our critical vocabulary. They suggest that critics may interpret the late works of artists as exceptional creative departures from earlier strands in the oeuvre due to an established critical expectation of such late style distinction, rather than finding a solid base for these assumptions, since 'late style's modern critical profile ensures that the predication of lateness enhances the aesthetic significance of all work so described simply by association with that same pantheon. ${ }^{15}$ I hope to overcome simplistic assignments of innovation and aesthetic significance by paying close attention to the specific ways in which novelistic narrative strategies become aesthetically relevant in service of an autobiographical act that is conditioned by lateness. Rather than attesting to a potentially opaque streak of genius on the side of Coetzee, Roth, and Grass, literary autobiography's late style points towards a continuous adaptation of novelistic narrative strategies to suit the representation of self, life, and lateness. Late style responds to and represents endings but it also contains resistance to the end because its rendering of lateness lasts beyond the author's life. How and with which kind of narrative stylistic choices does the novelist autobiographer create an 'experience' of lateness and ending?

To answer this question, I turn to Said. In his posthumously published book, On Late Style, Said explores the idea of 'late style' in artists' works which he develops from Theodor W. Adorno's concept of Spätstil (translated from German as 'late style') in Beethoven. ${ }^{16}$ He identifies two opposing types of lateness which he sees as a factor of style: lateness as expressing a resolution and maturity, which unites the artist's oeuvre in a spirit of reconciliation, and lateness as showing difficulty and tension through unresolved contradictions in an artist's late work. For Said, each of these types of lateness - reconciliation and contradiction - is distinct from the other, representing opposite impulses that can characterise an artist's late work. Both types of lateness mark a turn in the artist's work towards the end of their life or career which signals an aesthetic departure from earlier style or styles. On the one hand, lateness as a force of reconciliation distinguishes late works which 'crown a lifetime of aesthetic endeavor' by expressing mature 'harmony and resolution' and a climax of aesthetic transcendence that completes the artist's work as a whole with a sense of unity. On the other hand, lateness as encompassing tension shows 'intransigence, difficulty, and unresolved contradiction' as traits of late work which describes a struggle with diverging, even oppositional impulses. Said places a clear emphasis on lateness (and by extension late style) which mediates experiences of the latter, 'nonharmonious, 
nonserene,' 'going against' kind; in fact, On Late Style focuses entirely on examples of late style which fall into this category. ${ }^{17}$

I wish to showcase literary autobiography as a site of exposure for a crossing of boundaries between these seemingly distinct types of lateness as reconciliation and lateness as contradiction. To do so, I consider Roth's writing desk and his autobiographical work in The Facts and Deception:

Well, to begin to answer - the person I've intended to make myself visible to
here has been myself, primarily. Over fifty you need ways of making yourself
visible to yourself. [... ] My desk had become a frightening, foreign place
and, unlike similar moments earlier in life when the old strategies didn't
work anymore - either for the pragmatic business of daily living, those prob-
lems that everybody faces, or for the specialized problems of writing - and
I had energetically resolved on a course of renewal, I came to believe that I
just could not make myself over yet again. Far from feeling capable of remak-
ing myself, I felt myself coming undone. ${ }^{18}$

Autobiographical life writing within the framework of lateness revolves around contemplations concerning the self and its identity, specifically how the self - and who the self - came to be in the present state. This passage from the preface of Roth's The Facts: A Novelist's Autobiography clearly signposts the factor of lateness as a motivational force to write about himself, as he mentions his age '[o]ver fifty' as a reason for writing his life as a way 'of making yourself visible to yourself.' Indeed, the lateness of age is deepened even further in the triggering event of a physical and mental 'breakdown [...] which carried [Roth] [...] right to the edge of emotional and mental dissolution, ${ }^{19}$ thus disrupting his prolific writing career with the crisis of 'coming undone.' Lateness therefore asserts itself through a general loss of certainty about the self '[o]ver fifty' on the one hand, and as the direct result of illness and depression which threaten any stable sense of identity on the other hand. This corresponds to Said's assertion that extremes, such as death, crisis, and exile, are faced by artists 'with failing senses and memory' in the form of late style. ${ }^{20}$ Roth depicts the choice to write the life as a response to each of these extremes. Death in the form of 'a prolonged physical ordeal,' crisis in the form of mental instability, and exile in the form of losing access to one's identity frame the present impetus to recollect the past in an attempt to make the self 'visible' again.

The context of lateness in a crisis of the self as it directs Roth's impulse to write autobiographically also becomes particularly apparent in the image of his desk as 'a frightening, foreign place.' In fact, the writer's desk as a summary of the novelist's identity is described in detail in a later autobiographical work by Roth; that is, in Deception: A Novel. The 
protagonist, Philip, has his unnamed lover describe his studio where they meet with her eyes closed, and the details about his desk take up almost half of her account:

His desk, about three by five, consists of a gray metallic pedestal and a pale Formica top whose surface is not as orderly as his compulsiveness would lead you to expect, though he seems to know which uneven piles of papers is unfinished manuscript and which is a stack of unanswered letters and which contain the clippings about Israel that he cuts from the London papers to prove to her that the British are anti-Semitic. The typewriter, on a typing desk placed at right angles to the writing desk, is an IBM Correcting Selectric Two. Black and serious. A Prestige Pica Seventy-two gold ball. ${ }^{21}$

The fact that this description of the writer's desk claims considerable space in the overall account of the room becomes significant when Philip's lover turns the tables and challenges him to describe her. The proposed symmetry of this question and answer game then suggests that the account of the writer's studio, his work space, his desk, actually doubles as a reflection of his identity and self. Philip's traits of character are inscribed in the relation to his work place: 'his compulsiveness,' his interest in 'prov[ing] [...] that the British are anti-Semitic' and his typewriter as '[b]lack and serious' all serve to summarise conceptions about his identity as specifically writerly, Jewish and consumed by his work. Roth's statement in The Facts: A Novelist's Autobiography concerning the alienation from his desk gains further significance in relation to the perceived crisis about his identity when seen in conjunction with the strong link between writerly self and writing desk that is made in Deception: A Novel. The loss of stable selfhood which precedes the writing of The Facts: A Novelist's Autobiography is tied to a construction of writerly identity that distinguishes itself by being able to 'remak[e]' itself through the process of writing fiction. According to the preface of his autobiography, Roth's turn to life writing originates in the quest to recover a sense of himself as a writer, a novelist, in the face of lateness as exemplified by a physical and mental crisis of identity.

However, Roth's autobiography proves to be more complex than a simple turn to recounting his life from past to present; indeed the work's movement to salvage a seemingly lost conception of his self encapsulates, and in doing so challenges, Said's idea of late style as divided into the irreconcilable types of reconciliation and contradiction. As Michael Wood in his introduction to Said's On Late Style notes: 'Explorations of the making of the self can go until the very end; the self's unmaking is another affair, and late style comes close to that. ${ }^{22}$ Relying on Said's concept of opposing types of lateness - reconciliation and contradiction - Wood 
divides '[e]xplorations' surrounding selfhood into two corresponding notions: the 'making of the self' and the 'self's unmaking.' While the making of the self is supposedly based on an impulse of lateness to unify and harmoniously reconcile diverging ideas about the self into a stable sense of identity, the self's unmaking seems to refer to a practice of capturing lateness as a force of difficulty and tension in the fragmentation and dissolution of identity through late style. Upon first glance, life writing and autobiography obviously seem to focus on 'the making of the self (my italics M.S.)'; one expects to read how the artist, the intellectual, the writer, the autobiographer became who they are today, that is to say, the story of how they are made and made themselves. Yet, the novelist's account of their life which is spent writing fiction narrates how the writer's own story is fed into creating other stories. Thus, the novelist's self stands out by $m a k$ ing other, fictional selves, which in turn, overshadow or unmake the novelist's identity beyond his writerly persona. Writing emerges as a process by which the novelist's self is constituted while simultaneously destabilising the coherence of the novelist's life story by creating fictional alternatives, afterlives, and versions of the life lived only on the page. These fictional lives not only defy the ending of the novelist's life by being conserved in writing but they also reach beyond endings by suggesting a multiplicity of lived and imagined lives and selves. Fictionality thus offers the opportunity for various lives and selves to live on alongside and beyond the inevitable autobiographical ending of death.

Roth's autobiographical writing reflects this paradoxical condition of the writing life through his use of distinct narrative strategies and frameworks, which aim to convey a self-consciously constructed multiplication of the novelist's self. A prominent example of such a narrative move is already contained in the earlier quoted preface to The Facts: A Novelist's Autobiography. Unlike any conventional preface, the prologue of the work consists of a letter from Roth to his fictional character Zuckerman, which explains that a mental breakdown following an illness triggered the impulse to write autobiographically and not fictionally like before. The need to recover his identity as it was before his breakdown was mentioned as the motivation for recollection. After conceding that he changed the names of some of his recognizable acquaintances for the sake of their privacy, Roth asks Zuckerman for an evaluation of his autobiography's manuscript, specifically seeking his opinion about whether it should be published. This manuscript then follows, chronicling Roth's childhood in the Jewish community of Newark, his further education, his marriage to his first wife Josie as well as its decline and the beginnings of his literary career, followed by his separation from Josie, his relationship with May Aldridge, literary success with the publication of Portnoy's Complaint in 
1969, and Josie's death in a car accident the year before. The book concludes with Zuckerman's reply letter to Roth's initial request of assessing the enclosed manuscript, which advises him not to publish it. This inclusion of Zuckerman's character and voice into the autobiography through an epistolary framing of the autobiographical text constitutes a narrative strategy, which allows for the novelist's life story to be rendered within a dialogue between the autobiographer Roth and the fictional Zuckerman, whose voice is obviously also written by the author Roth. In other words, Roth's reconstruction of how his writerly self is made is destabilized in its certainty by the presence of a fictional alter ego, who unmakes this seemingly definite version of the novelist's identity by prompting questions about the status and value of autobiography as opposed to fiction in relation to the subjects of 'truth' and the self as well as 'truth' about the self and its significance:

\footnotetext{
What one chooses to reveal in fiction is governed by a motive fundamentally aesthetic; we judge the author of a novel by how well he or she tells the story. But we judge morally the author of an autobiography, whose governing motive is primarily ethical as against aesthetic. How close is the narration to the truth? [...] In a way we always tell in order not to tell, but the personal historian is expected to resist to the utmost ordinary impulse to falsify, distort, and deny. ${ }^{23}$
}

Roth, in the guise of Zuckerman, conceptualises the aesthetic versus the moral judgement of a work as the crucial difference between fiction and autobiography while also challenging the notion that the autobiographer or 'personal historian' could be able to resist the supposedly human impulse to lie and omit. As a result, a paradoxical conflation of indeterminate senses of the self emerges: A perceived loss of the writerly identity (the writer's desk) triggers a turn towards autobiographical life writing, yet within the autobiography a fictional counterpart to the life writing novelist undoes any sense of certainty about the life-story by presenting himself as a more authentic version of the autobiographer's self. Said's late-style as difficult, contradictory disharmony seems to creatively shape the narrative conception of this work, and yet the figure of the novelist which permeates each layer of the life story offers a curious possibility of reconciliation, of uniting the different alternatives inscribed in factual or fictional versions of the writerly self. After all, the writing desk is the very space in which a dialogue between the writer's fictional and factual worlds actually ensues through the writing process and thus constitutes a stable base for a novelist's self, suspended between 'reality' and fiction. It is an aesthetic of performative contradiction that allows the seemingly paradoxical existence of Zuckerman in The Facts: A Novelist's Autobiography to generate this fruitful, 
indeed reconciliatory, dialogue between the novelist's positions towards fact and fictionality. This figure of the novelist which is constructed as creatively straddling the fact fiction divide arises from the experience of lateness. However, through its affirmation of contradiction, it can also overcome autobiographical endings by imagining alternatives, such as Zuckerman.

\section{WRITING AUTOBIOGRAPHICAL MEMORY}

Are we not free to replace memories that distress us with invented memories that make us feel good? If we object to people making up their past, are our objections not purely and simply ethical? ${ }^{24}$

By posing this question to the psychologist Arabella Kurtz in their conversation recorded in The Good Story, Coetzee highlights a conflict that resonates with the very nature of autobiographical memory as constructed, subjective, and undercut by varying and conflicting motives, such as confession, testimony, self-understanding, and self-promotion. Autobiographical writing is conditioned by the unique authorial perspective of relating an account of the past that is initiated and structured according to a present impulse to look back in the first place. In psychological discourse, this very notion of surveying the past from the present moment has been called 'hindsight [...], the process of looking back over the terrain of the past from the standpoint of the present and either seeing things anew or drawing "connections." 25

Writing autobiographical memory can therefore be mapped out as a sequence: the author recalls experiences from the past actively and/or remembers in a sensuous, affective manner - both of which are likely to be triggered by a present impulse or motive - leading to a narrative shaping of the past in the form of memory that is then again reshaped or consolidated in some form through physical writing. What inevitably emerges from this chronology is the notion that hindsight features at least twice in the process, firstly in the moment of remembering, and then again in choosing a written form for the memory. Furthermore, the shape-giving, mediating force of narrativising, of engaging in narrative reflection, is shown to condition memory and remembering from the very beginning, given its ties to hindsight. Authors who write autobiographical memory are therefore always rewriting memories which are already narrativised from the moment of recollection.

Earlier, I quoted Coetzee, who enquires whether we are 'free to replace memories that distress us with invented memories. ${ }^{26}$ Given the relationship between memory and narrative as previously established through the 
idea of hindsight, one might even argue that memory is itself an invention by the present self, and that remembering is a flexible narrative process of imagining the past. Indeed, Kurtz responds to Coetzee's question with an affirmation of memory's inherent instability: 'I share your sense of the malleability of memory. Indeed the more I think about it, the more malleability seems to me intrinsic to the process of remembering. ${ }^{27}$ If memory and remembering are characteristically narrativised and malleable, then an autobiographer's ethical achievement lies neither in the closeness to truth their autobiography can accomplish nor in in their moral growth, but in the degree to which memory and remembering are communicated to the reader as complex, inevitably narrativised and imagined ideas.

In Grass's Die Box, the title giving artefact - a camera that is called 'the box' due to its characteristic shape - embodies a sense of hindsight, memory and remembering, which opens up imaginative spaces quite literally. The narrative setting of this autobiographical text is complex: the character of the father in this tale (an autobiographical version of Grass), imagines a situation in which his children would come together at the same table to exchange memories and experiences with and about their father as well as the camera which belonged to Marie. Marie, a friend of the father, has learnt photography professionally and after her husband dies, she is persuaded by the father to take pictures of objects and people that are important or interesting to him. Marie and her camera are the central theme of the text and structure its anecdotal chronology. Through her, the parallels between the camera as well as photography and memory or remembering are explored:

Waren große Wohnungen, fünf Zimmer, wie unsere. Doch weil man die Fenster alle von innen mit Brettern oder Preßspan vernagelt hatte, kam nur durch Ritzen Licht, so daß es überall schummrig, in manchen Ecken duster gewesen ist.

Mariechen hat trotzdem mit ihrer Box alles geknipst, [...]

Das meiste war verschmurgelt oder nach dem Brand weggeräumt worden, weil noch brauchbar...

\section{$[\ldots]$}

Soll absolut duster gewesen sein, haste gesagt. Und trotzdem hat die olle Marie mit ihrer simplen Box?

Aber ja doch, Taddel. Sogar ohne Blitzlicht hat sie geknipst. Wie immer, einfach vom Bauch weg und manchmal aus der Hocke raus. 
Klar, hätten wir uns denken können, wenn wir beide schon bißchen älter gewesen wären: Ist viel zu dunkel zum Fotografieren.

Sowas schafft die Box nie.

Schade um die Filme.

Doch als wir dann heimlich in Vater's Atelier geschlichen sind, [...], sahen wir die Fotos schön aufgereiht über seinem Arbeitsplatz an Dachbalken gepinnt, an denen außerdem sein Zettelkram mit den Hundenamen...

\section{$[\ldots]$}

Wollte keiner glauben zuerst: jedes Bild taghell ausgeleuchtet.

Nix verwackelt.

Jedes Möbel genau.

Doch sah man jetzt Wohnungen, die heil und bewohnt aussahen, auch wenn kein einziger Mensch in den Zimmern...

\section{$[\ldots]$}

Jede Einzelheit. Salzstreuer, Teelöffel und so, auch wenn die alte Marie ganz ohne Blitzlicht...28

[The flats were large, five rooms, like ours. But because the windows had all been boarded up with planks and pressboards, light only got in through cracks, so it was dim, really dark in some of the corners.

Marie nevertheless took snapshots of everything with her box, [...]

Most of it was charred, or had been removed because it could still be used...

\section{$[\ldots]$}

You said it was really dark. And yet, old Marie with her simple box?

But of course, Taddel. She even took the shots without flash. Just as always, from her tummy, sometimes when squatting.

Sure, if we had been a little older, we could have thought to ourselves, it's much too dark to take photos. 
The box will never make it.

Shame about the film used.

But when we secretly snuck into father's workshop, $[\ldots]$ we saw the photos nicely pinned up next to each other on the roof beam above his work place, where he also has all his notes and stuff about the dog names...

None of us could believe it at first: every picture was illuminated bright as day.

Nothing blurry.

Every piece of furniture precisely.

But now one could see flats that looked undamaged and inhabited, although not a single person was in the rooms...

Every single detail. Salt shaker, teaspoon and such, although old Marie, completely without flash... $]^{29}$

The above conversation recounts how Marie took pictures of some old, abandoned, and burnt out flats with her camera, but the fascinating detail about this seemingly mundane process lies in the images captured in the developed photos. Instead of showing the decay and deterioration of the flats interior or a dark, blurry impression of the settings - as if through some wonderful photographic miracle or skill the place as it used to be is pictured, '[j]ede Einzelheit' [every single detail]. Marie's and the camera's peculiar magic is shown to go beyond mere wish fulfilment. Instead, the photos taken by her with the box camera reveal how the place once was; they show the past although the pictures were taken in the present. Furniture and objects that are absent in the current state of the flats because they had been removed to be used as firewood, reappear on the photographs in startling quality and sharp detail.

Without Marie's authorship and the children's viewership, the photographs would not be distinguishable from ordinary photographs. Their showing of the past (or future) is contingent on minds that remember the places as they are or as they once were. Therefore, the parallels between the magical transformations of the photographed subjects within the 
camera to be shown on the developed photos and the processes of remembering through hindsight are numerous. Just as a person remembering looks at their past from a current moment, the box captures snapshots of the past by photographing a place in the present. It illuminates and reveals images that are presently shrouded in darkness and presents them in a seemingly definite and uncannily detailed fashion. This mirrors with compelling imagery, how the past that is often delineated by uncertainty is ordered and embellished through the structuring power of hindsight and remembering. Yet, the limitations of images and photos to show only sections, excerpts from a larger whole, point towards the unreliability, malleability, and partialness of memory. To take a photo is a deliberate act and involves efforts of composition, such as angling and finding a perspective or view from which to capture the image. Marie is said to do all of this technical process quite effortlessly, even carelessly, but together with the father and according to his interests in objects or spaces. Marie and her box camera thus function as a filter through which remembering as well as imagining of memory takes place. This externalisation of how recollection might work through hindsight and narrative resonates with the theme of imagined pasts, conversations and times that runs through the whole setting of the book. Layers of imagination and mediation of autobiographical material envelop Grass's selfrepresentation in this text, but narrative reflection through hindsight lies at its very core. The novelist's relationship to the past, to memory, and also to writing fiction is thus mirrored in an autobiographical portrait of its complex and contradictory entanglement. Such a way of writing autobiographical memory emulates the author's self-understanding, but it also communicates to the reader at every turn, that this self-understanding has to be understood as a narrative reflection, as coloured by hindsight and as an exercise in imagining memory, that ultimately has to be revealed as partial and subjective. The ethical move here lies in laying this process open for the reader, in letting the reader, so to speak, gaze into the box. Due to its allusion to fairy tales the fantastical element of the magical camera performs contradictions more subtly than the more intrusive presence of Zuckerman in Roth's autobiography. Nevertheless, Grass's box and its interpretation of memory also places the imagined alongside the autobiographical. Fictionality and imagination are therefore not only shown as inherent features of memory, they also counter autobiographical endings in the face of death by constructing multiple and enduring alternatives to the novelist's life that last beyond the inevitable end.

Literary autobiography, as exemplified in Coetzee, Roth, and Grass, employs narrative strategies otherwise found in fiction in order to 
creatively explore lateness, belatedness and a sense of ending with regard to the writing life. Performative contradiction with regard to lateness and style as well as memory and imagination, as a deliberate stylistic manifestation of paradoxical contradictions, is a result of such narrative strategies. Performative contradiction can be achieved through varying contrasts of autobiographical and fictional conventions, using different narrative frameworks. While Coetzee adopts a position of striking self-scrutiny by imagining the creation of his posthumous biography, Roth addresses assumptions of autobiographical resemblance between himself and his protagonists more playfully through the inclusion of Zuckerman in his autobiography. Meanwhile, Grass evokes the genre and tradition of the fairy tale, contrasting the fantastical magic of the box camera more subtly with expectations of autobiographical referentiality. Despite distinct differences in scales and types of narrative strategies, an aesthetic aim of engendering contradiction is common to these examples. By creating an aesthetic of performative contradiction, literary autobiography acknowledges the fraught and instable nature of writing both against and in reconciliation with the inevitability of death.

The novelist thus succeeds in holding both the end and a multiplicity of pasts and futures in suspension by emulating a life that is permeated by this very contradiction, through the writing that creates the life of an author. By exposing the other (or several others) that Smith and Watson observe as 'internal to every autobiographical subject,' ${ }^{30}$ the novelist highlights the inseparable relationship between the imagined and the real in autobiographical discourse. As Coetzee considers in Youth, fiction and reality affect each other in a cyclical motion:

Of course Emma Bovary is a fictional creation, he will never run into her in the street. But Emma was not created out of nothing: she had her origin in flesh and blood experiences of her author, experiences that were then subjected to the transfiguring fire of art. If Emma had an original, or several originals, then it follows that women like Emma and Emma's original should exist in the real world. And even if this is not so, even if no women in the real world is quite like Emma, there must be many women so deeply affected by their reading Madame Bovary that they fall under Emma's spell and are transformed into versions of her. They may not be the real Emma but in a sense they are her living embodiment. ${ }^{31}$

Here, the autobiographical subject of Coetzee reflects on the possibility of meeting Emma Bovary outside of her character's story. As John Frow discusses in Character and Person, our conceptions of selfhood and personhood influences and is in turn influenced by an understanding of fictional characters as 'quasi-persons. ${ }^{32}$ Coetzee touches on this 
relationship between 'actual' and fictional persons by arguing that inspirations for Emma must have been drawn from real-life women and experiences, since 'Emma was not created out of nothing' and thus the idea of encountering these 'flesh and blood experiences of her author' is not impossible. In the opposite way, meeting women who are 'so deeply affected by their reading Madame Bovary' that they 'are transformed into versions of her' seems like an equally logical possibility. While these musings on the potential extra textual iterations of a fictional character can easily be related to a broader relationship between real-life experiences and 'the transfiguring fire of art,' they hold equal salience in relating an author's life, their autobiographical rendering thereof and its sense of an ending. Just as Emma Bovary might have pre- and post-fictional ties to real women, the novelist autobiographer defines and simultaneously is defined by the autobiographical subject he or she creates. Yet, the extent to which the autobiographical version of the novelist becomes his or her written 'embodiment' seems to rely on the degree of sincerity that is perceived through the consistent revelation of writing and life as mutual fabrications of one another. Instead of contemplating the chances of 'run[ning] into' possible versions of Emma Bovary on the street, Coetzee could have described his own autobiographical self which is having these thoughts as a product of 'flesh and blood experiences [...] subjected to the transfiguring fire of art.' The exposure of this 'fire' enables literary autobiography to continuously confront us with contradiction, with the defiant imagination of multifaceted futures and selves in the face of death and endings. Literary autobiography thus emerges as a form of life writing, that is, just as Coetzee in Summertime, dead and alive, past and future.

\section{ABOUT THE AUTHOR}

Dr Melissa Schuh completed her PhD titled The (Un-)Making of the Novelist's Identity in the English department at Queen Mary University of London in 2019 and is a lecturer in English Literature at ChristianAlbrechts-University Kiel. Her research interests include English and German contemporary fiction, specifically the works of Philip Roth, J.M. Coetzee and Günter Grass, autobiography and life writing, as well as seriality and Modernism. Recent publications include an article on Günter de Bruyn in German Life and Letters, titled 'Das "richtige Leben im falschen" - Autoritäre Systeme und die Einheit von Widerstand und Anpassung in Günter de Bruyn's Zwischenbilanz und Vierzig Jahre' (2018). E-mail:schuh@anglistik.uni-kiel.de 


\section{WORKS CITED}

Adorno, Theodor W. 'Spätstil Beethovens'/'Late Style in Beethoven.' In: Richard Leppert (ed.), Essays on Music. Berkeley/Los Angeles/London: University of California Press, 2002, 564-568.

Attwell, David. J.M. Coetzee and the Life of Writing: Face to Face with Time. London: Penguin, 2015.

Coetzee, J. M. and Arabella Kurtz. The Good Story: Exchanges on Truth, Fiction and Psychotherapy. London: Harvill Secker, 2015.

Coetzee, J. M. Summertime. London: Vintage, 2010 (First published 2009).

Coetzee, J. M. Youth. London: Vintage, 2003 (First published 2002).

Currie, Mark. Postmodern Narrative Theory. Basingstoke: Palgrave Macmillan, 2011.

Dix, Hywel. 'Introduction: Autofiction in English: The Story so Far.' In: Hywel Dix (ed.), Autofiction in English. London: Palgrave Macmillan, 2018, 1-23.

Freeman Mark. Hindsight: The Promise and Peril of Looking Backward. Oxford: Oxford University Press, 2010.

Frow, John. Character and Person. Oxford: Oxford University Press, 2016.

Gilmore, Leigh. 'Learning from Fakes: Memoir, Confessional Ethics and the Limits of Genre.' In: Susana Onega and Jean-Michel Ganteau (eds.), Contemporary Trauma Narratives - Liminality and the Ethics of Form. London: Routledge, 2014, 21-35.

Grass, Günter. Die Box: Dunkelkammergeschichten. Göttingen: Steidl Verlag, 2008.

Kannemeyer, J. C. J.M. Coetzee: A Life in Writing. London: Scribe, 2012.

Kermode, Frank. Sense of an Ending: Studies in the Theory of Fiction. Oxford: Oxford University Press, 2000.

Leeder, Karen. 'Figuring Lateness in Modern German Culture.' New German Critique 42 (2015) 1-29.

McMullan, Gordon and Sam Smiles. 'Introduction.' In: Gordon McMullan and Sam Smiles (eds.), Late Style and its Discontents: Essays in Art, Literature, and Music. Oxford: Oxford University Press, 2016, 1-12.

Richter, Gerhard. Afterness: Figures of Following in Modern Thought and Aesthetics. New York: Columbia University Press, 2011.

Roth, Philip. The Facts: A Novelist's Autobiography. London: Vintage, 2007 (First published 1988).

Roth, Philip. Deception: A Novel. London: Vintage, 2006 (First published 1990).

Said, Edward W. On Late Style. London: Bloomsbury, 2006.

Smith, Sidonie and Julia Watson. Reading Autobiography. Minneapolis: University of Minnesota Press, 2002.

Wood, Michael. 'Introduction.' In: Edward W. Said (ed.), On Late Style. London: Bloomsbury, 2006, ix-xiv.

\section{NOTES}

1 Coetzee, J. M. Summertime. London: Vintage, 2010 (32).

2 For a consideration of the whole trilogy, see for example Kossew, Sue. 'Scenes from Provincial Life (1997-2001).' In: Tim Mehigan (ed.). A Companion to the Works of J.M. Coetzee. Rochester, NY: Camden House, 2011, 9-22.

3 Coetzee. Summertime, 44.

4 Rather than 'he or she', 'they' is used as a gender-neutral and non-binary pronoun in this article. 
5 Both David Attwell and J.C. Kannemeyer have used related turns of phrase to describe a close relationship between Coetzee's life and writing. Attwell titles his literary biography of Coetzee 'J.M. Coetzee and the Life of Writing: Face to Face with Time,' while Kannemeyer subtitles his biography 'A Life in Writing.' See Attwell, David. J.M. Coetzee and the Life of Writing: Face to Face with Time. London: Penguin, 2015; Kannemeyer, J. C. J.M. Coetzee: A Life in Writing. London: Scribe, 2012.

6 Currie, Mark. Postmodern Narrative Theory. Basingstoke: Palgrave Macmillan, 2011 (79).

7 Coetzee. Summertime, 242.

8 Richter, Gerhard. Afterness: Figures of Following in Modern Thought and Aesthetics. New York: Columbia University Press, 2011 (2).

9 Said, Edward W. On Late Style. London: Bloomsbury, 2006 (14).

10 Dix, Hywel. 'Introduction: Autofiction in English: The Story so Far.' In: Hywel Dix (ed.). Autofiction in English. London: Palgrave Macmillan, 2018, 1-23.

11 Gilmore, Leigh. 'Learning from Fakes: Memoir, Confessional Ethics and the Limits of Genre.' In: Susana Onega and Jean-Michel Ganteau (eds.), Contemporary Trauma Narratives - Liminality and the Ethics of Form. London: Routledge, 2014, 21-35 (23).

12 Leeder, Karen. 'Figuring Lateness in Modern German Culture.' New German Critique 42 (2015) 1-29 (1).

13 Kermode, Frank. Sense of an Ending: Studies in the Theory of Fiction. Oxford: Oxford University Press, 2000 (181).

14 Richter. Afterness, 2.

15 McMullan, Gordon and Sam Smiles. 'Introduction.' In: Gordon McMullan and Sam Smiles (eds.), Late Style and its Discontents: Essays in Art, Literature, and Music. Oxford: Oxford University Press, 2016, 1-12 (1).

16 See Adorno, Theodor W. 'Spätstil Beethovens'/'Late Style in Beethoven.' In: Richard Leppert (ed.), Essays on Music. Berkeley/Los Angeles/London: University of California Press, 2002, 564-568.

17 Said. On Late Style, 6-7.

18 Roth, Philip. The Facts: A Novelist's Autobiography. London: Vintage, 2007 (4-5).

19 Idem, 5.

20 Said. On Late Style, 146, 24.

21 Roth. Deception: A Novel. London: Vintage, 2006 (38).

22 Wood, Michael. 'Introduction'. In: Edward W. Said (ed.), On Late Style. London: Bloomsbury, 2006, ix-xiv (xvii).

23 Roth. The Facts, 2007, 163-164.

24 Coetzee, J. M. and Arabella Kurtz. The Good Story: Exchanges on Truth, Fiction and Psychotherapy. London: Harvill Secker, 2015 (19).

25 Freeman, Mark. Hindsight: The Promise and Peril of Looking Backward. Oxford: Oxford University Press, 2010 (4).

26 Coetzee and Kurtz. The Good Story, 19.

27 Idem, 22.

28 Grass, Günter. Die Box: Dunkelkammergeschichten. Göttingen: Steidl Verlag, 2008 (37-38).

29 Translation is my own.

30 Smith, Sidonie and Julia Watson. Reading Autobiography. Minneapolis: University of Minnesota Press, 2002 (67).

31 Coetzee. Youth, 25.

32 Frow, John. Character and Person. Oxford: Oxford University Press, 2016 (107). 